\title{
Student Teachers' Self-Efficacy: Appraisal from the Perspective of Professional Competence
}

\author{
Lysinge née Magdalene Limunga Njoh \\ B.A. (Hons) in English, Dipen II. M.Ed (Hons) EPY, PhD in View \\ Faculty of Education, University of Buea, Cameroon, Central Africa
}

\begin{abstract}
Self-efficacy beliefs, which are the confidence student teachers have in their professional competence are closely related to academic and professional training outcomes. The purpose of this study was to appraise the effects of student teachers' selfefficacy on their professional competence.
\end{abstract}

One research questions and hypothesis was formulated to guide the study. It was a survey research. A sample of 323 student teachers selected purposively from five Government Teacher Training Colleges in the South West Province completed an adapted version of teacher-efficacy scale developed by Woolfork-Hoy (1990). The data were analysed using the Statistical Package for the Social Sciences (SPSS) Software version 12.0 for windows.

The finding showed that self-efficacy of student teachers was high and they tended to have above average scores in academic performance.

The results were discussed and some recommendations and suggestions for further studies have been made.

Prevent kidney cancer quit smoking, maintain a healthy weight, control high blood pressure, life style modification can reduce incidence of cancer.

Keywords: Student Teachers, Self-Efficacy, Appraisal, Perspective, Professional, Competence

\section{INTRODUCTION}

Personal experience in Government Teacher Training Colleges (GTTC) has shown that some student teachers always complain about the tedious nature of training programmes and sometimes want to give up. They are uncertain about their personal capabilities as far as teaching is concerned. They are often afraid of the teaching practice sessions, and sometimes get confused when a teacher supervisor or evaluator is around. They sometimes fear their cooperating teachers. Some are equally afraid of the future when they would be fully employed. Such feelings of uncertainty make them to look at the future with pessimism.

According to Bandura $(1980 ; 1997)$ such student teachers have low self-efficacy. Other student teachers find that the programme is tedious, but they make honest efforts to overcome the difficulties. They seek help from the cooperating teachers and their school supervisors. They often initiate helpful discussions amongst their peers and approach teaching practice sessions with more positive expectations. They are eager to face the future successfully. Bandura (1980; 1997) would refer to such people as having high self-efficacy. Efficacy beliefs of pre-service teachers have been linked to attitudes towards children and control (Woolfolk and Hoy, 1990).

From the inception of teacher training programmes in the 1920s, the demand for trained teachers has steadily increased, following the increase in the number of nursery and primary schools.The growth of teacher education witnessed the introduction of a three-year course for elementary teacher training, which lead to the teacher Grade
I certificate. Entry has always been through a competitive examination with a minimum qualification of the First School Leaving Certificate. The three-year programme was not terminal but provided grounds for continuous training (Ndongko and Tambo, 2000). In the 1980s, more teacher training colleges were opened in all the provinces of Cameroon. With time, people with only the First School Leaving Certificate were no longer qualified for admission. This was simply because of the rise in the level and standard of education.

Three categories of student teachers are admitted today into the nursery and primary teacher training colleges. Those who enroll with three or four ' $O$ ' Level G.C.E subjects undergo three years of training. Some exceptional cases with First School leaving certificate do three years. Those who enroll with four ' $O$ ' level and one 'A' level G.C.E subjects do two years. Those with any of the above qualifications who have been teaching in the nursery or primary schools are qualified to do the nine months course. Those who also enroll with two 'A' Level G.C.E subjects or its equivalence have nine months of training. All the student-teachers in the various levels of the training programmes are required to have as least six weeks of teaching practice in both nursery and primary schools annually. The major objective of these training programmes is to furnish the future teachers with skills that are necessary for the effective discharge of their pedagogic activities. The quality of nursery and primary school teachers is crucial as these teachers are responsible for the growth and development of children at an impressionable period of their lives (Tambo, 2000). 
The teacher-training programmes consist of two major parts; the course work and teaching practice. They emphasize the theory and practice of education. The course work consists of at least 29 subjects of professional and academic subjects. To be successful, the student teacher needs adequate theoretical knowledge in education and the ability to apply such knowledge in the practical context. The professional courses provide the insight into children's needs, motives and behaviour as individuals. Meanwhile, the academic disciplines provide the essential knowledge in the subject matter required for classroom teaching. The second part is the teaching practice, which is seen as a genuine professional internship. The student teachers are placed under the supervision of their teachers and cooperating teachers who give them practical training. In his discussion of the significance of teaching practice, Awoniyi (1979) states, "the training colleges provide the teacher with the necessary initiation into a profession where consistent and continuous practice and acquisition of experience are absolutely necessary for his/her improvement in the field". At the end of their professional training the student teachers should possess a broad repertoire of classroom behaviours and skills, as well as professional and academic knowledge. They are also expected to write and defend term papers.

Bandura's $(1977,4986)$ social cognitive theory which stands as the backbone of this study. It brings out three factors that make up one's self- efficacy. They include: Behavioural factors, cognitive factors and environmental factors. These three factors influence each other. Bandura refers to them as reciprocal determinism. Achievement behaviour is influenced by cognitive factors like expectation, beliefs, attitudes intelligence etcetera, as well as environmental factors like school, teachers and available resources etcetera. Details of these will be seen in the next chapter.

Silverman and Casazza (2000) state that the effects of high and low competence beliefs are significant in that "High self efficacy (competence) beliefs result in enhanced effort during difficult tasks, reduced stress in taxing situations and the choice of goals that are challenging and that sustain interest and involvement. Low self-efficacy beliefs result in reduced effort, tendencies to give up when faced with difficult tasks.

Increased attention to personal deficiencies, the development of avoidance behaviour, increased anxiety and stress, and the likelihood of lowered aspiration leading to the reverse of self efficacy which is learned- helplessness". It is also important to note that mastery experiences reinforce beliefs of competence (self-efficacy). Successes tend to raise a person's level of self-judgement, whereas failures tend to lower it. Individuals with a series of successful experiences are usually able to tolerate an occasional failure with little or nooverall effect on their positive personal efficacy beliefs. Easy successes however do not facilitate positive selfefficacy beliefs and should not be encouraged as a way to change self judgement (Casazza, 2000).

Even though several researchers have investigated the relationship of self-efficacy to learning and academic achievement, more is still being done particularly with more attention to academic performance. (Lent, Brown and Larkin 1986); (Multon, Brown and Lent, 1991; Schunk, 1994). In this review, two major factors examined are; personal and teaching efficacy. Personal efficacy has to do with how much effort will be applied to attain an outcome, the level of persistence applied to the task in the face of difficulties or setbacks and style of attribution (Bandura 1977, 1982, 1997). Ryan and Cooper state that the teachers personality is the most critical .factor in successful teaching. If teachers have warmth, empathy, sensitivity, enthusiasm and humour, they are more likely to be successful than if they lack these characteristics. They further warn that four major types of teacher altitudes affect teaching behaviour. They include attitude towards self, attitude towards children, attitude towards peers and parents and attitude towards the subject matter. Teaching efficacy represents the confidence to teach, use instructional innovation and manage classrooms (Woolfolk Hoy, 2000).

Meanwhile professional competence deals with the expert knowledge that one has in canying out a task. Every society has certain functions to be performed if life within that society has to be sustained and the quality maintained or improved upon. There are societies that create work specialization and invent institutions and organizations that facilitate delivery and improvement of services. These are done because of the need for professional competence. Howsam, Corrigan and Denemark (1985) note that "professionals have a strong service motivation and lifetime commitment to competence". Professionals are people who have been educated in most valid knowledge and skills in a particular field. The professionals have expert knowledge. Lortie (1984) states that professional competence has to do with knowledge, skills, behaviours, attitudes and values that constitute the bases for professional expertise and decisionmaking. Trained teachers must draw from what they have as professional knowledge and intervention strategies in order to decide how to help children.

The Government Teacher-Training Colleges (G.T.T.C) specifically train teachers for the nursery and primary level of education so that the student teachers should have expert knowledge. Tambo and Ndongko (2000) highlight the raison d'etre of professional training when they state;

"(i) Human relationships and their impact on school and classroom activities, (ii) factors influencing individual differences in pupils and the ways of taking account of these differences, (in) problems of classroom communication, especially language, the art of questioning, skills in explaining, describing, narrating, (iv) that learning environment, motivation and discipline, (v) class, group and individual work, (vi) understanding lesson patterns; implications for lesson planning, (vii) techniques of presentation, (ix) methods of assessments, test construction, and curriculum planning, (x) planning schemes of work, integrated approach to teaching, topic work, use of resources and visual aids; (xi) strategies for coping with large class size ", are phenomenon in the schoolsystem which should be examined with care.

According to Lortie (1984), having gone through a professional training course, the nursery and primary school teachers must have developed the various disciplinary techniques and managerial skills essential for the' creation of effective learning situations. Other aspects of professional competence would be the student teachers ability to relate teaching activities and personal experience with children and educational studies. All of these would lead to confidence in the student teachers. On the other hand most people who are not professionals may confront circumstances where their own ability is inadequate to protect them. 
According to Howsam, Corrigan and Denemark (1985) there are about eleven broad-based roles played by professional teachers.

"They should know hew to conduct needs assessments. They should know about the present and future. They should know how to utilize effectively people, time, space, equipment's and materials for instructional purposes. They should know how to assess teaching and learning. They lead and they follow. They function in places called schools; they function equally as educators in other settings. They can design learning activities. They are competent. They are accountable".

The above quotation emphasizes the dedication and effort necessary to go through the teacher-training programme. The beliefs of student- teachers about their future teaching competence helps to determine the level of effort they put in training and the outcome. Those who are confident anticipate successful outcomes in their training programmes as they will be able to meet with future challenges in the teaching field. The concept of self-efficacy has been used to describe people's beliefs about their competence. According to Bandura's $(1980 ; 1997)$ social cognitive theory, selfefficacy beliefs influence the choices people make and the ' courses of action they pursue. Confident individuals approach difficult tasks as challenges to be mastered rather than as threats to be avoided. Student-teacher beliefs play a crucial role in the development of teacher's professionalism (Smylie, 1997). This is because the beliefs filter the perception and interpretation of new knowledge and this influences how student teachers learn to teach, plan to teach, make instructional decisions and interact with pupils (Boiko and Putnam, 1996; Richardson and Placier, 2001).

Contextually, self-efficacy in this study addresses the beliefs that student teachers of government teachers training colleges have with respect to their professional competence. Competence in them come about as a result of the theoretical knowledge through course-work to effective teaching through the number of teaching practice sessions they undergo. After these experiences, they should be able to judge whether they are effective in handling classroom activities such as the competence in transmitting the subject matter, competence in classroom control and management competence in evaluating pupils work as well as the competence in motivating pupils to study meaningfully. Becoming a competent student teacher implies adapting to the dynamic nature of the teaching profession. Bandura (1986) highlights that one's self efficacy shows one's ability to control one's feelings, thoughts and actions which in turn influences one's actual performance, emotion, choice of behaviour, amount of effort and perseverance expended on a activity. This simply brings out the idea that student teachers who are hardworking have high self-efficacy.

Inspite of the challenges involved, they are able to write out their lesson notes within the stipulated period, prepare their aids, do their corrections following comments made by their teachers and approach the teaching practice with the determination to succeed. But most often the student teachers complain, about the tedious nature of the teaching programmes and show a lot of reluctance in carrying out responsibilities. There are a few students teachers who demonstrate competent beliefs based on their performance. Such student- teachers are willing to take responsibility for their pupil's academic output. There are some who may be moderate in their efficacy-beliefs. Real pedagogues ought to master challenges and put in much effort to handle or solve the problems and equally assume responsibility for the various outcomes. There are differences in student teachers' beliefs about their ability to teach.

\section{Statement of the Problem}

One of the major problems faced by some of the student teachers is that they are not sure of themselves with respect to teaching. They do not manifest self-confidence during teaching practice sessions and are equally very tense especially when a teacher is around. They are concerned about communication skills during teaching and discussions. It is also common for such students to attribute their failure to factors like pupils' family background, lack of stationeries and so on. They are also not certain as to whether they can really help break-up pupils from negative or difficult influences. Most of these student teachers show boredom, and are pessimistic about future teaching. "Low-efficacy teachers blame failure on students' family background and motivation, deprecate low achievers, and stratify their classrooms according to ability since such student-teachers may not want to be accountable for pupils' failures or negative outcome. They may not also want changes for the better" (Weber and Omotani, 1995).

Another problem is that sometimes even average ability student teachers fail to study specific subject areas; consequently they have difficulties in teaching the subject matter in the classroom. In other words student teachers who have not mastered the subject matter and all other professional skills tend to have less self-confidence during teaching practice. Although both male and female students face this problem, it seems to be more prevalent among female student teachers.

This study sets out to appraise student teachers' self-efficacy as far as their professional competence is concern.

\section{Objective of the study}

The major objective of the study was to examine the effects ofStudent teachers' self-efficacy on their professional competence.

\section{Research Question}

What is the level of student teachers' personal-efficacy?

\section{Research Hypothesis}

Ha: There is a significant relationship between student teachers' personal efficacy and teaching efficacy.

$\mathrm{Ho}_{2}$ : There is no significant relationship between student teachers' personal efficacy and their teaching efficacy.

\section{BACKGROUND TO THE STUDY}

Self-efficacy refers to the "beliefs in ones capability to organize and execute the course of action required managing prospective situations". Operationally, self-efficacy refers to student teachers' judgments about their ability to handle future teaching activities.

A lot of writers have published academic papers and studies relating to children learning and self efficacy. Among these writers is Albert Badura $(1977,1986)$ as cited in Santrock (2004) postulates that children can design the late of their academic life. He says when children learn, they can cognitively represent or transform their experiences when 
the need arises. He is the major architect of the concept of self-efficacy. He developed three main factors that make up self-efficacy: behaviour, cognitive factors and the environment. The factors are commonly known as the "triadic reciprocity" or "reciprocal determinism". He uses the diagram as shown below (figure 1) to explain why the three factors influence one another

Figure 1: The diagram showing reciprocal determinism Behaviour e.g. achievement behaviour

$\begin{array}{ll} & \text { Success/failure } \\ \text { Cognitive Factors E. G. } & \text { Environment E. G. } \\ \text { - Expectation } & \text {-School } \\ \text { - Beliefs - } & \text {-Teacher } \\ \text { - Attitudes - } & \text {-Learning Resources } \\ \text { - Strategies -Thinking - } & \text {-Resource Centres } \\ \text { - Intelligence - } & \text {-Reading Corner }\end{array}$

To explain the diagram, cognitive factors such as expectation, beliefs, attitudes, strategies, thinking and intelligence influence behaviour, fBehavioural elements such as achievement behaviour that is success or failure also influence cognitive factors. Environmental factors like [ schools, teacher, learning resources, resource centre, and reading comer influence behaviour. Meanwhile, behaviour equally influences the | environment. For instance, the studyskill programs developed by the school or teacher also improve the achievement behaviour of many in the class. This will also cause teachers, or the school to expand the program, l so that all schools will participate in it.

It is also seen in that diagram that cognition influences environment. The expectation and planning of the school principal and teachers made the study skills program possible in the first place. Finally, environmental factors influence cognition. For instance the school establishes a resource centre where students can go to check out books and materials to improve their study-skills, There are some factors that lead to the development of self-efficacy, but it is worth knowing that the initial sources of self-efficacy are centered in thefamily. Bandura, (1997), Meece (1997) postulate that parents who provide stimulating environment for their children help to stimulate children's curiosity. Such environments encourage creativity in children

f and also provide mastery experiences that help to build children's self- I efficacy. They continue to say that environments that are rich in I interesting activities offer challenges to the children and motivate them to [work hard. Children who display more curiosity and do exploratory I activities promote parental responsiveness. The judgment that people I make about their capabilities whether accurate or not are often based on I the following sources, which include: enactive experience, vicarious | experience and verbal persuasion.

Enactive experience is a highly influential source of selfefficacy. Successful experiences raise self-efficacy with regard to target performance. For instance the greater feelings of self-competence produce increased effort and persistence on a task ultimately lead to a higher level of performance (Vasta, Haith, and Miller 1992). On the other hand, any experience of failure or repeated failure creates low efficacy beliefs, which usually result to reduced effort at a task and tendencies to give up in the [face of difficult tasks. Increased attention to personal deficiencies and the development of avoidance behaviour lead to the likelihood of lowered aspirations or learned-helplessness (Bandura, 1986).

The second source of efficacy information is vicarious experience, which is through observation. Observing peers, or peer models especially those with perceived similar capabilities develops ones self-efficacy. Observing peers succeed can raise an observer's self-efficacy and motivate him/her to perform the task if he/she believes he/she will be successful (Schunk, 1987). Conversely, observing others fail can lead I students to conclude that they lack the competence to succeed; this can dissuade them from attempting the task. Models are most influential for students who are uncertain about their capabilities, or who are notfamiliar with the task, or those who have experienced difficulties and hold doubts (Bandura, 1986; Schunk, 1987). Modelling is also backed by Bandura's social learning theory in which he insists that people learn by imitating the behaviour of other models. This is very applicable to student teachers because, when they observe, their teachers, cooperating teachers and mates teach, they tend to observe and imitate. This improves their teaching efficacy especially if they are given reinforcement. According to Bandura during such interaction, an individual may learn to modify his or her behaviour as a result of how others in the group are responding.

According to Bouffared - Bouchard, (1989) as cited in Sundberg (1997) convincing people serve as another source of efficacy information. Teachers, for example, can raise or inhibit students' perception of their efficacy by suggesting whether or not they have the capabilities to succeed in a given task. Models can also be used to demonstrate to selfdoubters that personal capabilities are more often a result of effort rather than innate capability. Physiological indicators are also sources of self-efficacy information. People often have physical reactions to anticipated events.

Many develop sweaty palms, nervous vocal reaction when talking and fast I rate of heart beat because of fear or anxiety. This is typical of people with low self-efficacy (Baumrind 1973).

The conceptual differences between self-efficacy and selfconcept I are not always clear to researchers. Sometimes some authors use the terms I synonymously; others describe self-concept as a generalized form of self- efficacy. But selfefficacy is the judgment of the confidence that one has in one's abilities, while self-concept is the knowledge people acquire [about themselves with respect to their physical appearance, physical ability, gender, intellectual abilities and interpersonal skills (Marion, 1999). The development of selfconcept begins firstly with selfrecognition that is, recognizing one's self as a distinct entity.' Secondly individuals see themselves through others, what Cooley (1988) calls "the looking-glass self', Mead (1934) adds that "we often come to know ourselves by imaging what significant others think of us, and then incorporating these beliefs into our evaluation of our self-worth.

According to Bong and Clark (1999), as cited in Liyod\&Weiten (2000) self-concept beliefs are not accessed at task specific levels. Self- efficacy beliefs revolve around 
questions of "can" (Can I write well? Can I drive a car? Can I solve this problem?), whereas self-concept beliefs reflect questions of "being" and "feeling" (Who am I? Do I like myself?

How do I feel about myself as a writer?) The answers to the self-efficacy $>$ questions that individuals pose to themselves reveal whether they possess high or low confidence to accomplish the task or succeed at the activity in question. The answers to the self-concept questions that individuals pose to themselves reveal how positively they view themselves, as well as how they feel in those areas. Selfefficacy is contextually bound while self- concept is culturally bound,

According to Santrock (2001) the following are some good strategies for improving students' self-efficacy.

1. Teach students specific strategies, such as outlining and summarizing, that can improve their ability to focus on their task.

2. Guide students in setting goals, especially in creating short-term goals after they have made long-term goals. Short-term goals especially, help students to judge their progress.

3. Give students performance - contingent rewards, which are more likely to signal mastery, rather than rewards for merely engaging in tasks.

4. Combine strategy training with an emphasis on goals and give feedback to students on how learning strategies relate to their performance. This combination can enhance students' self-efficacy and skill development.

5. Provide students with support. Positive support can come from teachers, parents, and peers. So statements from teachers like "you can do this" would motivate students to work harder.

6. Make sure that students are not overtly aroused and anxious. When students worry and agonize about their achievements, their self- efficacy diminishes.

Provide students with positive adult and peer models. Certain characteristics of these models can improve student self-efficacy. For example, students who observe teachers and peers cope effectively and master challenges often adopt the models' behaviours. Modelling is especially effective in promoting self-efficacy when students observe success by peers who are similar in ability to themselves. One positive way for teachers to use peer modeling in improving students' self-efficacy is to have each work on some aspect of a task and then have the students explain their parts to other group members after they have mastered it.

\section{METHODOLOGY}

The survey research design was used for this study. This was because the researcher wanted to get the views about the various beliefs and behaviours of student teachers from the different Government Teacher Training Colleges.

The population for this study was made up of student teachers from government teacher training colleges in the South West Province. There are Seven Teacher Training Colleges, but only five were randomly selected for this study. The five colleges include:

1. Government Teacher Training College (G.T.T.C.) Buea

2. Government Teacher Training College (G.T.T.C.) Kumba

3. Government Teacher Training College (G.T.T.C.) Limbe
4. Government Teacher Training College (G.T.T.C.) Fontem 5. Government Teacher Training College (G.T.T.C.) Mamfe

A sample of 323 student teachers from five G.T.T.Cs was used for this study. Student teachers from all the classes participated in the study. The selection was done at two levels. Firstly* five G.T.T.Cs were randomly selected. Seven student teachers who represented the seven G.T.T.Cs had to pick folded papers on which 'Yes' or 'No' was written. Those who picked the papers with 'yes' written on them were taken for the schools selected and those with 'no' were left out.

The Second level of selection was concerned with participants for the study. This was done through cluster sampling technique. This was employed because the enrolment of the G.T.T.Cs is not high. Instead of randomly selecting a sample of student teachers, the researcher thought it wise to use all the student teachers enrolled in the selected schools. Therefore, the student teachers in each school constituted a cluster. This exercise was carried at the end of the academic year 2005/2006.

Table 1: Presents the sample.

\begin{tabular}{|c|c|c|c|c|}
\hline \multirow{2}{*}{ School } & \multirow{2}{*}{ Level } & \multirow{2}{*}{ Sample } & \multicolumn{2}{|c|}{ Gender } \\
\hline & & & Boys & Girls \\
\hline \multirow{3}{*}{ G.T.T.C Buea } & $1^{\text {st }}$ year & 8 & 1 & 7 \\
\hline & $2^{\text {nd }}$ year & 27 & 6 & 21 \\
\hline & $3^{\text {rd }}$ year & 50 & 7 & 43 \\
\hline Sub-Total & 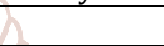 & 85 & 14 & 71 \\
\hline \multirow{3}{*}{ G.T.T.C Limbe } & $1^{\text {st }}$ year & 9 & 0 & 9 \\
\hline & $2^{\text {nd }}$ year & 12 & 1 & 11 \\
\hline & $3^{\text {rd }}$ year & 27 & 3 & 24 \\
\hline Sub-Total & 8 & 48 & 4 & 44 \\
\hline and & $1^{\text {st }}$ year & 42 & 5 & 37 \\
\hline \multirow{2}{*}{ G.T.T.C Kumba } & «nd 2 year & 38 & 7 & 31 \\
\hline & $3^{\text {rd }}$ year & 24 & 13 & 11 \\
\hline Sub-Total & 9 & 104 & 25 & 79 \\
\hline \multirow{3}{*}{ G.T.T.C Fontem } & $1^{\text {st }}$ year & 6 & 1 & 5 \\
\hline & $2^{\text {nd }}$ year & 4 & 0 & 4 \\
\hline & $3^{\text {rd }}$ year & 8 & 0 & 8 \\
\hline Sub-Total & & 18 & 1 & 17 \\
\hline \multirow{3}{*}{ G.T.T.C Mamfe } & $1^{\text {st }}$ year & 23 & 7 & 16 \\
\hline & $2^{\text {nd }}$ year & 20 & 5 & 15 \\
\hline & $3^{\text {rd }}$ year & 25 & 8 & 17 \\
\hline Sub-Total & & 68 & 20 & 48 \\
\hline Grand Total & & 323 & 63 & 260 \\
\hline
\end{tabular}

Table 3.1 shows that the sample consisted of 260 female and 63 male student teachers from the five colleges. There were 88 first years, 101 second years and 134 third years.

Data were collected using a questionnaire that was developed by the researcher

The validation of the instrument was done in two phases. Phase one involved pilot testing with 20 student teachers of G.T.T.C Limbe. Their responses showed that the items were understood. Her supervisor through thorough checking and verification of items did the second phase of the validation. The researcher was then given the go ahead to distribute the copies to the various colleges.

The copies of the questionnaire (323) were administered to the various respondents in the five-selected G.T.T.Cs .The researcher made contacts with the various principals 
through phone calls and letter writing. The attestation showing that the researcher is indeed a postgraduate student in the University of Buea was attached to each of the letters sent out to the colleges. It was only after receiving the principal's approval that the researcher or her assistant visited the colleges.

The researcher personally handed some questionnaire to the Government Teacher Training Colleges of Buea, Limbe and Kumba, respectively. Meanwhile the rest were sent through travelling agencies to the various schools in areas that were far away. The completed copies of the questionnaire (292) were returned within one week.

In scoring the teacher efficacy scale, Gibson and Dembo: long fonn was used. Construct validly of the 22-item efficacy scale was based on Wool folk and Hoy (1990) prospective teaching efficacy (T E) and personal efficacy ( P E ). These were two independent factors.

Some of the items were reversed because they did not indicate a strong sense of efficacy. Giving the 1= "strongly agree" response to the statement, ${ }^{* *}$ when I try really, I can get through to most difficult pupils" must be reversed so that the respondent receives a score of 6 rather than l.To determine the $\mathrm{T} E$ and $\mathrm{P}$ E scores, the researcher computed unweighed means of the items that loaded.35 or higher on each respective factor.

Data collected with the use of questionnaire were coded and entered into a spreadsheet. The Statistical Package for the Social Sciences (SPSS) software version 12.0 for windows was used in analysing the data. Descriptive and inferential statistics were used. Descriptive statistics included frequencies, percentages, means, standard deviations and variance.

Inferential statistics were used. The Pearson correlation coefficient test statistics and $\mathrm{Z}$ - test (student $\mathrm{t}$ - test equivalent for large sample). These tests were carried out at 0.05 level of significance. Below is the formula for the Z-test

The formula for Z-test is:

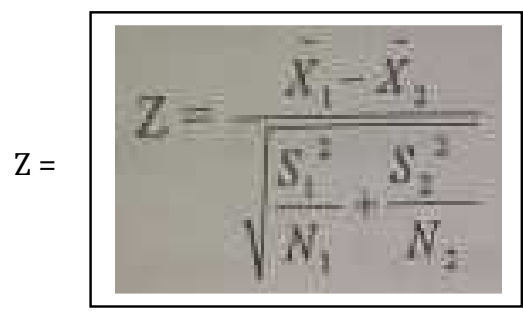

Where:

$\mathrm{X},=$ mean for group 1

$X_{2}=$ mean for group $2 S^{2}=$ Variance for group 1

$S_{2}{ }^{2}=$ Variance for group 2

The formula for Pearson correlation coefficient is

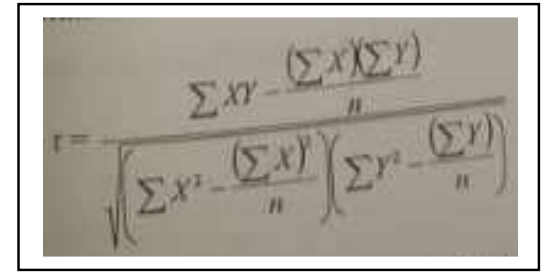

\section{FINDINGS}

The first part of this presentation deals with demographic information.

Demographic Information: Gender of Respondents

\begin{tabular}{|c|c|c|}
\hline Gender & F & $\%$ \\
\hline Male & 50 & 17.1 \\
\hline Female & 242 & 82.9 \\
\hline Total & 292 & 100 \\
\hline
\end{tabular}

Table shows that there were 242 (82.9\%) female and 50

$(17.1 \%)$ male participants.

There were more female than male respondents.

This distribution is also displayed in figure 2.

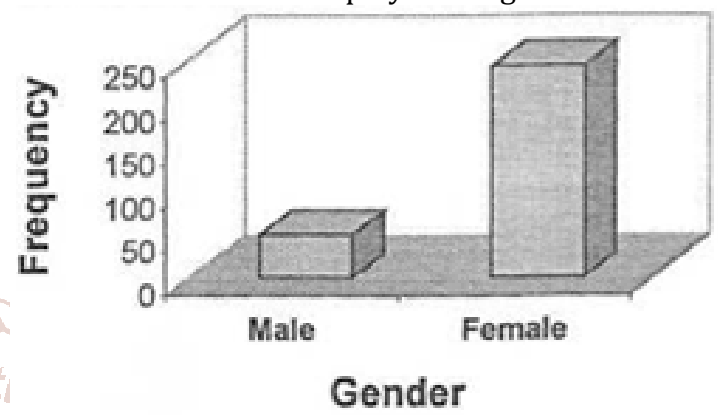

Figure: Distribution of Respondents According to Gender

Table: Distribution of Respondents According to Year of Entry into GTTC

\begin{tabular}{|c|c|c|}
\hline Year of Entry & $\mathbf{F}$ & $\%$ \\
\hline $3^{\text {rd }}$ & 24 & 8.2 \\
\hline $2^{\text {nd }}$ & 94 & 32.2 \\
\hline $1^{\text {st }}$ & 174 & 59.6 \\
\hline Total & 292 & 100 \\
\hline
\end{tabular}

Table above shows that there were $24(8.2 \%)$ students in the third year, $94(32.2 \%)$ in the second year and $174(59.6 \%)$ in the third year. This reflects the distribution of student teachers enrollment in GTTCs according to length of the courses for which they were admitted. Thus most candidates were enrolled for one-year training course, followed by two years and then three years.

\section{Presentation of the statistics}

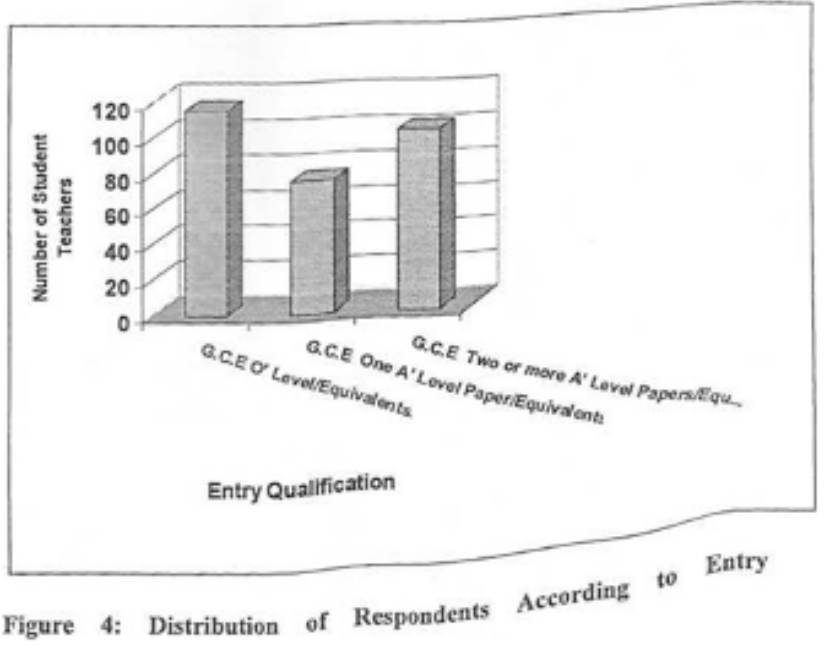


International Journal of Trend in Scientific Research and Development (IJTSRD) @ www.ijtsrd.com eISSN: 2456-6470

\section{Qualification}

Table: Distribution of Respondents According to Entry Qualification into GTTC

\begin{tabular}{|l|c|c|}
\hline \multicolumn{1}{|c|}{ Entry Qualification } & F & $\%$ \\
\hline G.C.E O' Level/Equivalents & 115 & 39.4. \\
\hline G.C.E One A' Level Paper/Equivalents & 75 & 25.7 \\
\hline $\begin{array}{l}\text { G.C.E Two or more A' Level } \\
\text { Papers/Equivalents }\end{array}$ & 102 & 34.9 \\
\hline \multicolumn{1}{|c|}{ Total } & $\mathbf{2 9 2}$ & $\mathbf{1 0 0}$ \\
\hline
\end{tabular}

Table above shows that $39.4 \%$ (115) of the student teachers had G.C.E 0/Level or its Equivalents, 25.7\% (75) had one G.C.E A/Level paper and 34.9\% (102) had two or more A/Levels.

Table: Distribution of Respondents According to Class in GTTC

\begin{tabular}{|c|c|c|}
\hline Class & $\mathbf{F}$ & $\%$ \\
\hline One & 38 & 13 \\
\hline Two & 76 & 26 \\
\hline Three & 178 & 61 \\
\hline Total & 292 & 100 \\
\hline
\end{tabular}

From the table above, most of the student teachers 178 $(61 \%)$ are in class three whereas very few of them $(13 \%)$ are in class one. The distribution of student teachers according to classes in GTTCs is displayed graphically in the figure

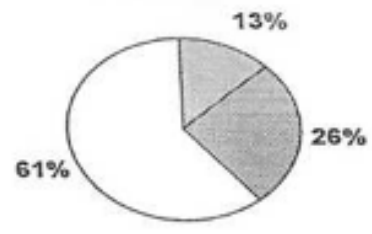

Figure: Distribution of Student Teachers into Classes

\section{Second Term Average scores in Examination}

The respondents were asked to indicate their average scores for first and second terms of the current academic session. The results are shown on table below.

Table: Distributions of Student Teachers According to Terminal Average scores

\begin{tabular}{|c|c|c|c|c|}
\hline Average & \multicolumn{2}{|c|}{ First Term } & \multicolumn{2}{c|}{ Second Term } \\
\hline (Range) & $\mathrm{F}$ & $\%$ & $\mathrm{~F}$ & $\%$ \\
\hline$(8-10)$ & 15 & 5.1 & 17 & 5.8 \\
\hline$(11-13)$ & 170 & 60.3 & 160 & 54.8 \\
\hline$(14-16)$ & 28 & 9.6 & 37 & 12.7 \\
\hline Missing Value & 73 & 25 & 78 & 26.7 \\
\hline Total & 292 & 100 & 292 & 100 \\
\hline
\end{tabular}

The third term results were not available at the time the questionnaire was administered. Table above shows that some respondents did not indicate their first and second term average scores (missing values). For the first term, 73 $\mathbf{2 5 \% )}$ of the students did not give their average scores and in the second term 78 (26.1\%) did not also indicate their average scores. Of those who indicated their average scores in the first term, $28(9.6 \%)$ had $14-16 ; 170(60.3 \%)$ had 11-13 and 15 (5.1\%) had 8-10, on 20. In the second term, $37(12.7 \%)$ had $14-16 ; 160$ (54.8\%) had11- 13 and 17 (5.8\%) had 8-10. The majority of the students had average scores above 10 on 20 .

The Level of Student Teachers' personal-efficacy The level of student teachers' self-efficacy was measured in terms of their outcomes expectancy (personal efficacy) based on the instruction on the Teacher Self-efficacy instrument adopted for this study items $1,5,6,7,8,11,12,13,14,16,18$ and 19 measure personal efficacy. The means, standard deviations and variance of items relating to teacher personal efficacy are presented on table below.

Distribution of Student Teachers according to First and

\begin{tabular}{|c|c|c|c|c|}
\hline$S / N$ & ITEMS & MEANS & SD & VARIANCE \\
\hline 1 & $\begin{array}{l}\text { When a pupil does better than usual, many times it is because I exert a little extra } \\
\text { effort. }\end{array}$ & 5.33 & 0.87 & 0.76 \\
\hline 5 & I have enough training to deal with any learning problem. & 4.88 & 1.39 & 1.94 \\
\hline 6 & $\begin{array}{l}\text { When a pupil is having difficulty with an assignment, I am usually able to adjust } \\
\text { it to his /her level. }\end{array}$ & 4.82 & 1.45 & 2.12 \\
\hline 7 & $\begin{array}{l}\text { When a pupil gets a better grade than he/she usually gets, it is usually because I } \\
\text { found better ways of teaching that pupil }\end{array}$ & 5.24 & 1.16 & 1.33 \\
\hline 8 & When I really try, I can get through to most difficult pupils & 4.85 & 1.36 & 1.86 \\
\hline 11 & $\begin{array}{l}\text { When the grades of my pupils improve, it is usually because I found more } \\
\text { effective approaches. }\end{array}$ & 5.21 & 1.26 & 1.58 \\
\hline 12 & $\begin{array}{l}\text { If a pupil masters a new concept, this might be because I knew the necessary } \\
\text { steps in teaching that concept. }\end{array}$ & 5.52 & 1.00 & 1.00 \\
\hline 13 & If parents would do more for their children, I could do better. & 1.66 & 1.24 & 1.54 \\
\hline 14 & $\begin{array}{l}\text { If a pupil did not remember information I gave in a previous lesson, I would } \\
\text { know how to increase his/her retention in the next lesson }\end{array}$ & 2.03 & 1.52 & 2.31 \\
\hline 16 & $\begin{array}{l}\text { If a pupil in my class becomes disruptive and noisy, I feel assured that I know } \\
\text { some techniques to redirect him/her quickly. }\end{array}$ & 5.21 & 1.34 & 1.79 \\
\hline 18 & $\begin{array}{l}\text { If one of my pupils couldn't do a class assignment, I would be able to accurately } \\
\text { assess whether the assignment was at the correct level of difficulty. }\end{array}$ & 3.94 & 1.74 & 3.02 \\
\hline \multirow[t]{2}{*}{19} & $\begin{array}{l}\text { If I really try hard, I can get through to even the most difficult or unmotivated } \\
\text { pupils. }\end{array}$ & 4.78 & 1.48 & 2.20 \\
\hline & Total & 53.47 & 15.81 & 21.45 \\
\hline
\end{tabular}

Table above shows that the least mean is 1.66 and the highest is 5.52 .

Total Mean $=53.47$ 


\section{Total Number of Items $=12$}

Therefore the mean for student teachers' Personal Efficacy = $53.47 / 12-4.46$. Thus student teachers personal efficacy is high

The results show that the level of student teachers' selfefficacy is high. This is confirmed by their first and second term average scores (see table above). Grades are said to be important predictors of self-efficacy because the student teachers are motivated to work and have confidence because of their previous results. This findings support Vasta, Haith and Miller (1992) when they maintain that successful experience raise self -efficacy with regard to target performance. Bandura (1997) is also supported by this finding when he stipulated that most students are able to predict their outcome in their course work if their level of confidence is high and ability to execute course of action is also high. Personal efficacy expectations are said to influence initiating behaviour, how much effort will be applied to attain an outcome and the level of persistence applied to the task to face the difficulties and setbacks.

\section{Conclusion}

The whole issue about self-efficacy is the belief one has about one's competence. It is a motivational construct, which induces action and determines the choice people make in life. The ultimate goal of all learners is to succeed, so their various competence beliefs are paramount in their decision to succeed. The ability to act intentionally must be present as well as the ability to have control over one's environment and social structures. The social cognitive theory has provided a detailed explanation on how the learners' behavioural and environmental information create their self - beliefs that in turn inform and alter subsequent behaviour and environments.

Parents and policy makers usually blame the failure of students on teachers and schools, rather, the study habits of the students should be blamed. It is true that both teachers and schools have a part to play, but the bulk of the work lies in the hand of the learners. It would be good if student teachers understand that the starting point of all achievements is definiteness of purpose with a positive mental attitude. If a student teacher believes that he/she can succeed, then he/she can, if he/she invests the required effort to handle a task.

Mastery experiences are the most influential source of selfefficacy information. The educational implication of this is that it provokes self-enhancement in academic achievement and increases student teachers achievement in schools. Student teachers need to understand that low self-efficacy beliefs provoke a negative mental attitude and a cobweb mind. Most often, student teachers fail because they are not motivated to work hard. They can change their beliefs by developing a positive mental attitude. Failure is not an end but a means to inform one that, more effort is needed, and the right strategies should be used. Teachers and schools including parents have a major role to play here. This might help to motivate the students to succeed.

\section{Recommendations}

1. Student teachers should be aware of the fact that the judgments made about their competence in their teaching are crucial components if they have to succeed. If they believe that they are going to fail then they will fail and the reverse will also be true.

They really need to manifest confidence during teaching practice.
2. Student teachers should always take their own share of responsibility for pupils' academic output. This will enable them to prepare their lessons well and teach well.

lf-efficacy on student teachers' locus of control.

\section{REFERENCES}

[1] Ashton, P.T. \& Webb, R.B., (1986). Making a difference: Teachers'sense of efficacy and student achievement. New York Longman..

[2] Awoniyi, T. (1979). Principals and practice of Education. London Hodder and Stoughton.

[3] Bandura, A. (1997).Self-efficacy: The exercise of control: New York W.H. Freeman and Company.

[4] Baumrind, D. (1973). The development of instrumental competence through socialization. Minneapolis: Minnesota Press.

[5] Bruner, J. S. (1978) toward atheory of Instruction. Cambridge. Massachusetts London. Harvard University Press.

[6] Feldman, S.R. (2000). Essentials of understanding psychology. Fourth edition, New York The McGraw-Hill Companies, Inc.

[7] Flanders, N.A. (1973) Knowledge about Teacher Effectiveness. New York. Me Graw-Hill Lie.

[8] Hoffman L., Paris S., Hall E. J and Schell R. Developmental Psychology Today.5th edition. New York.

[9] Howsam, R.B., Corrigan, D. C, Denemark, W.D (1985). Educating a Profession. Washington American Association of Colleges for Teacher Education.

[10] Liebennan M. (1960). Education as a profession. New York Prentice- Hall.

[11] Liyod J. \&Weiten C. (2000). Psychology applied to modem life. $6^{\text {th }}$ Edition. New York McGraw-Hill Companies Inc.

[12] Ndongko, T. M. \& Tambo, L.I. (2000). Educational Development in Cameroon 1961 - 1999, issues and perspectives. Platleville, Madison: MkemnjiEilobal Tech.

[13] Papalia, E.D. \& Olds, W.S. (1992). Human Development.5th Edition, New York. McGraw-Hill Companies Inc.

[14] Rayan K. \& Cooper J. (1988). Those who can teach. Boston. Hougthon Mifflin Company.

[15] Sadker M. P. \&Sadker D.M. (2000). Teachers, School and Society $5^{\text {th }}$ Edition. New York McGraw Hill Companies.

[16] Santrock, W.J. (2001). Educational Psychology. New York. McGraw-Hill Companies Inc.

[17] Sharon L. Silvennan Martha E. Casazza (2000). Learning and development: making connections to enhance learning. New York. Permission department, John Wiley and Sons, 605 3rd Avenue.

[18] Sprinthall N. A. and Sprinthall R. C. (1990). Educational psychology. A Developmental Approach. $5^{\text {th }}$ Edition. New York. Me Graw-Hill Inc.

[19] Steinbeiy, L. (1985). Adolescence: New York. Allred A Knopt Inc. $1^{\text {st }}$ Edition.

[20] Sundberg M. D. (1997). Assessment of persons. New Jersey. Prentice-Hall Inc.

[21] Tchome, T.M. (2004) Psychological parametersin Teaching Yaounde Presses Univeisitaire $\mathrm{d}^{5}$ Afrique.

[22] Vasta R., Haith M.M, Miller AS. (1992). Child psychology. The Modem Science. New York. Permission department, John Wiley and Sons, 605 3rd Avenue.

[23] Wool folk Hoy A. (2000). Changes in teacher efficacyduring the early years of teaching. New Orleans, LA American Educational Research Association. 